\title{
The Welding of Dissimilar Joints with Low Temperature Martensitic Transformation Filler Material
}

\author{
Cristiana dos Santos Nunes ${ }^{1}$, Hamilton Ferreira Gomes de Abreu ${ }^{1}$ (D), Cleiton Carvalho Silva ${ }^{1}$, Hélio Cordeiro de Miranda ${ }^{1}$, \\ Ladislav Novotnýr, Maria Cindra Fonseca ${ }^{3}$ \\ ${ }^{1}$ Universidade Federal do Ceará - UFC, Departamento de Engenharia Metalúrgica e de Materiais, Fortaleza, CE, Brasil. \\ ${ }^{2}$ Technical University of Košice, Department of Computer Aided Manufacturing Technologies, Košice, Slovakia. \\ ${ }_{3}^{3}$ Universidade Federal Fluminense - UFF, Departamento de Engenharia Mecânica, Rio de Janeiro, RJ, Brasil.
}

Received: 12 Nov., 2018

Accepted: 14 Feb., 2019

E-mails: cristiana.nunes@gmail.com (CSN), hamilton@ufc.br (HFGA), cleiton@metalmat.ufc.br (CCS), hmiranda@ufc.br (HCM), ladislav. novotny@gmail.com (LN), mcindra@ vm.uff.br (MCF)
This is an 0pen Access article distributed under the terms of the Creative Commons Attribution Non-Commercial License which permits unrestricted non-commercial use, distribution, and reproduction in any medium provided the original work is properly cited.
Abstract: The welding of dissimilar joints is very common in systems used in oil exploration and production in deep waters. This commonly involves welding low carbon steel pipes with valves, pumps or other pipes, all of them made of alloy steel. Inconel has been used in such welding as filler material; however, this welding is preceded by a process of buttering in the low alloy steel side and a stress relief heat treatment. An alternative technique presented in this paper is the use of a welding filler metal that, during the cooling process, undergoes a martensitic transformation at a relatively low temperature, so that the resulting deformation processing offsets the contraction that occurs as a result of the cooling process. This study evaluates the application of Maraging 250 weld in a dissimilar joint of the oil industry. Tests were performed on joints of ASTM steels A516 grade 70 and AISI 8630M welded with Maraging 250. The residual stress profiles, hardness, microstructure, tensile strength and impact energy absorbed were evaluated. The welded joint with Maraging 250 showed a high intensity of compressive residual stress. The microstructure of different welding regions was analysed and compared.

Key-words: Welding; Maraging; Dissimilar joints.

\section{Soldagem de Juntas Dissimilares com Material de Enchimento com Baixa Temperatura de Transformação Martensítica}

Resumo: A soldagem de juntas dissimilares é muito comum em sistemas utilizados na exploração e produção de petróleo em águas profundas. Comumente envolve a soldagem de tubos de aço de baixo carbono com válvulas, bombas ou outros tubos, todos feitos de aços ligados. Vem sendo prática nessas soldagens a utilização de Inconel como material de enchimento; no entanto, esta soldagem é precedida por um processo de amanteigamento no lado de aço baixa liga e um tratamento térmico de alívio de tensões. Uma técnica alternativa apresentada neste trabalho é a utilização de um metal de enchimento de solda que durante o processo de resfriamento sofre uma transformação martensítica em uma temperatura relativamente baixa, de modo que o processamento de deformação resultante compensa a contração que ocorre como resultado do processo de resfriamento. O objetivo deste estudo foi avaliar a aplicação de arame de solda Maraging 250 em uma junta dissimilar típica da indústria do petróleo. Os ensaios foram realizados em juntas de aços ASTM grau A516 70 e AISI 8630M soldadas com Maraging 250. Foram avaliados perfis de tensão residual, dureza, microestrutura, resistência à tração e energia de impacto absorvida. A junta soldada com maraging 250 apresentou altos valores de tensões residuais compressivas. As microestruturas de diferentes regiões de soldagem foram analisadas. O enchimento de solda Maraging 250 mostrou grande potencial de aplicação quando juntas dissimilares dessa natureza estão presentes.

Palavras-chave: Soldagem; Maraging; Articulações dissimilares.

\section{Introduction}

The welding of dissimilar joints of low carbon steel pipes with low alloy forged steels, sometimes with internal coating of nickel alloys, is a challenge in the oil and gas industry [1,2]. They are usually high thickness joints that require high levels of energy in the welding process. It is common for the joint on the side of the low alloy forged steel to go through a buttering process with carbon steel electrode prior to welding the joint. The buttering process is followed by a process of residual stress relief. The conventional way of reducing the level of residual stresses has always been to act during the design 
or to promote post-weld heat treatments. The first of these solutions often leads to a loss of efficiency while the heat treatment is sometimes logistically very complicated. An alternative technique when dealing with welding of steels is to induce an adiffusional phase transformation during the cooling of the weld [3,4]. When austenite is transformed into martensite or bainite the phase transformation results in an invariant plane deformation and a normal plane expansion. Each austenite grain can turn into up to 24 different crystallographic variants. If each variant deforms, the deformations of each variant will cancel each other out and the final macroscopic deformation will be only the change of volume. However, if external stresses act during the transformation, the phenomenon of variant selection happens. This selection of variants can counteract the tensile stresses arising from the cooling. It is very important that these transformations occur at temperatures low enough to allow the stress balance to be maintained at room temperature [5].

Ohta et al. [6] and Wang et al. [7] induced martensitic transformations in welded joints and showed a significant increase in crack propagation resistance in these welds. They developed a filler metal with $10 \% \mathrm{Ni}$ and $10 \% \mathrm{Cr}$ and a low martensitic transformation value $\left(\mathrm{Ms}=180^{\circ} \mathrm{C}\right)$.

Murakawa et al. [8] investigated the effect of the martensitic transformation start temperature on residual stresses in welded thin sheets. Figure 1 shows data from this study, obtained by simulation for longitudinal stress values in a weld using welding materials with initiation of martensitic transformation according to Table 1.
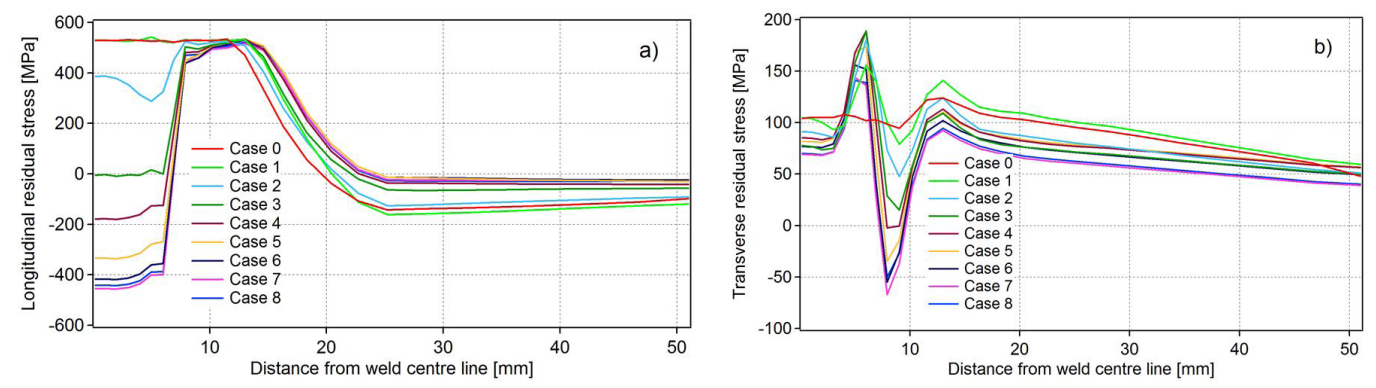

Figure 1. Prediction of residual stresses: (a) longitudinal; (b) transversal [3].

Table 1. Ms and Mf values for the cases presented in Figure 1.

\begin{tabular}{ccc}
\hline Case & Ms $\left[{ }^{\circ} \mathbf{C}\right]$ & Mf $\left[{ }^{\circ} \mathbf{C}\right]$ \\
0 & n/a & n/a \\
1 & 750 & 635 \\
2 & 650 & 535 \\
3 & 550 & 435 \\
4 & 450 & 335 \\
5 & 350 & 235 \\
6 & 250 & 135 \\
7 & 150 & 35 \\
8 & 100 & -15 \\
\hline
\end{tabular}

With the decrease in the temperature Ms, the stress near the centre line of the weld decreases and becomes compression when the temperature Ms falls below $500{ }^{\circ} \mathrm{C}$. The stress reaches a minimum (maximum value of compression) of about $-420 \mathrm{MPa}$ when the Ms temperature is below $150^{\circ} \mathrm{C}$. Similar trends are observed for the transverse stress (Figure 1b), i.e. the stress decreases with the lowering of the transformation temperature.

$\mathrm{Ni}$-Co-Mo-Ti quaternary-based Maraging steels are able to combine excellent toughness with high mechanical strength and belong to a family of materials with a martensitic transformation start temperature (Ms) below $200{ }^{\circ} \mathrm{C}$ and, even without final heat treatment of aging, has superior mechanical strength to that of the carbon and low alloy steels used in these dissimilar welded joints [9-11]. 
In this study, dissimilar welded joints of AISI 8630 wrought steel were welded to an ASTM A-516 grade 70 steel plate using a Maraging 250 steel rod as filler metal, and then evaluated concerning residual stress measurements, mechanical properties including a uniaxial tensile test, microhardness and Charpy- $\mathrm{V}$ impact test, as well as microstructural characterization.

\section{Materials and Methods}

The materials used for the present study were the base metals AISI 8630M, ASTM A517 G70 and the Maraging 250 steel filler metal in the form of a rod. Their chemical compositions are presented in Tables 2, 3 and 4, respectively.

Table 2. Chemical composition of the AISI 8630M steel.

\begin{tabular}{ccccccccc}
\hline $\mathbf{C}$ & $\mathbf{S i}$ & $\mathbf{M n}$ & $\mathbf{P}$ & $\mathbf{C r}$ & $\mathbf{M o}$ & $\mathbf{N i}$ & $\mathbf{C u}$ & $\mathbf{A l}$ \\
0.36 & 0.3 & 0.86 & 0.006 & 0.93 & 0.38 & 0.81 & 0.06 & 0.02 \\
\hline
\end{tabular}

Table 3. Chemical composition of the base metal ASTM A516 G70.

\begin{tabular}{ccccc}
\hline $\mathbf{C}$ & $\mathbf{M n}$ & $\mathbf{P}$ & $\mathbf{S}$ & $\mathbf{S i}$ \\
0.28 & 0.85 & 0.025 & 0.025 & 0.15 \\
\hline
\end{tabular}

Table 4. Chemical composition of the Maraging 250 steel filler metal.

\begin{tabular}{ccccccccccc}
\hline & \multicolumn{10}{c}{ Element (wt\%) } \\
\cline { 2 - 10 } & Sample & $\mathbf{C}$ & Si & Mn & Ni & Co & Mo & Al & Ti & Fe \\
MG 701 TIG (Maraging 250) & 0.02 & 0.50 & 0.10 & 19.25 & 7.5 & 4.6 & - & - & Balance \\
\hline
\end{tabular}

In order to comply with the requirements of ASTM [12], NACE MR0175 / ISO 15156 [13], which establish the criteria for weld joint approval, including the maximum hardness value of $22 \mathrm{HRC}$, AISI $8630 \mathrm{M}$ steel was quenched and tempered. The parameters of the applied heat treatments are in Table 5.

Table 5. Heat treatment parameters.

\begin{tabular}{cccccc}
\hline Sample & Thickness $(\mathbf{m m})$ & Treatment & Temperature $\left({ }^{\circ} \mathbf{C}\right)$ & Time $(\mathbf{m i n})$ & Cooling \\
\multirow{2}{*}{$8630 \mathrm{M}$} & \multirow{2}{*}{30} & Quenching & 860 & 30 & Agitated water \\
& & Tempering & 700 & 180 & Air \\
\hline
\end{tabular}

The TIG manual welding process was used to produce the dissimilar joint test plate. The welding was performed with preheating and it was used with restriction in order to reduce residual distortions and minimize the movement of parts during welding. Sixty five (65) weld beads of MG 701 TIG (Maraging 250) filler metal were deposited. The shielding gas used was pure argon and the arc welding source was an Invertec V250-S from Lincoln Electric manufacturer, optimized for TIG welding. The welding parameters are shown in Table 6.

Table 6. Welding parameters used in the experimental procedure.

\begin{tabular}{cccc}
\hline Voltage (V) & Current (A) & Welding speed (mm/min) & Heat input (kJ/mm) \\
15 & 170 & 57.7 & 2.65 \\
\hline
\end{tabular}


The welding was performed according to the technical drawing of the cross-section shown in Figure 2. The AISI 8630M steel base metal had straight faces while the ASTM A516 Gr70 steel base metal was machined and prepared with a chamfer in $1 / 2 \mathrm{~V}$ with a $45^{\circ}$ angle, both distanced at $3 \mathrm{~mm}$ for application of the root pass. The dimensions of the base metals were $250 \times 100 \times 30( \pm 3) \mathrm{mm}$.
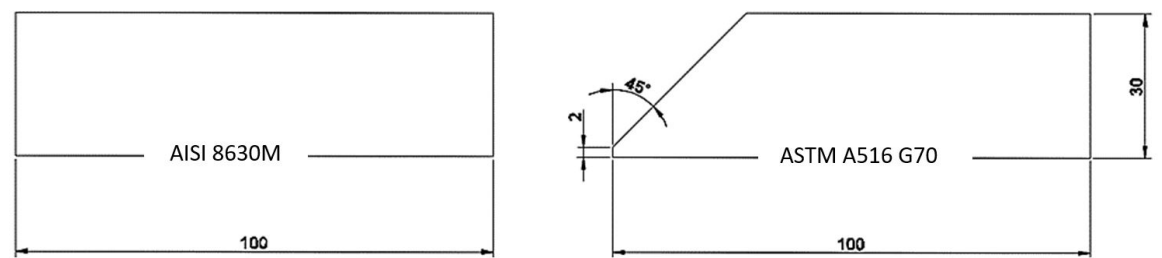

Figure 2. Cross-section of the constituent parts of the joints.

The residual stresses of the welded joint were measured by X-ray diffraction using the Xstress 3000 (X-ray Stress Analyzer, v.1.22e) with Crk $\alpha$ radiation, $2 \theta=156^{\circ}$, diffracting the plane $\{211\}$ from the ferritic phase. The $\operatorname{sen}^{2} \psi$ method, based on Bragg's Law, was used for each measure of stress. The diffraction peaks of five angles of inclination $\psi$ were determined. For this study, the inclination angles were $0^{\circ}, 20^{\circ}, 30^{\circ}, 40^{\circ}$ and $45^{\circ}$. To measure the changes in the lattice spacing, the operating voltage was $30 \mathrm{kV}$ and the current $6.7 \mathrm{~mA}$.

In the weld joint, regions were selected to perform residual stress measurements in both the transverse direction and the longitudinal direction of the weld bead. These regions were divided as follows: one point in each base metal neighbouring the interface between the base metal and the solder; a point on each base metal spaced apart from the interface line between the base metal and weld and a point on each bead of the weld metal, as shown in Figure 3. The distance between the measurement points of the residual stress analysis is in Table 7.

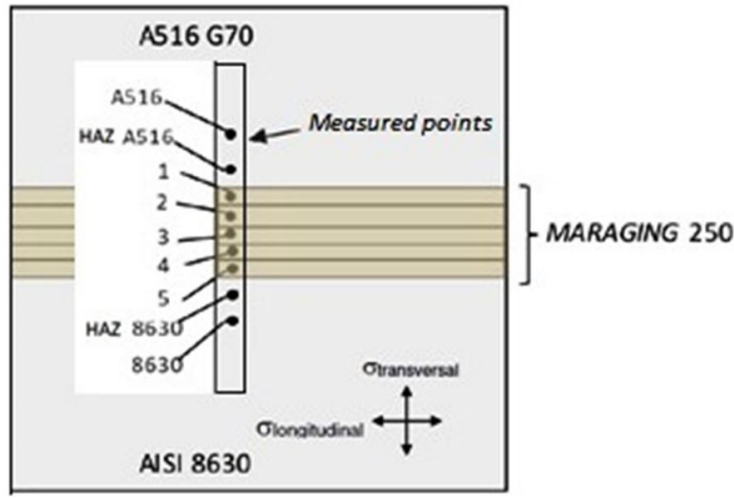

Figure 3. Schematic drawing of the location on which X-ray measurements have been performed.

Table 7. Distance and measured points to residual stress analysis.

\begin{tabular}{cc}
\hline Points & Distance $(\mathbf{m m})$ \\
A516 & -32 \\
HAZ A516 & -24 \\
1 & -16 \\
2 & -8 \\
3 & 0 \\
4 & 8 \\
5 & 16 \\
HAZ8630 & 24 \\
8630 & 32 \\
\hline
\end{tabular}


The uniaxial tensile tests were performed at room temperature. The tensile specimens were drawn from the cross- section of the welded joint in accordance with the recommendations of DNV-OS-F101 and ASME IX standards [14,15]. The dimensions of the specimens applied in the tests were standard size in accordance with ASTM A370 [16].

The Charpy impact test was performed on standard size test specimens of dimensions $55 \mathrm{~mm} \times 10 \mathrm{~mm} \times 10 \mathrm{~mm}$, in accordance with specifications of ASTM E23-07 [17], DNV-OS-F101 [14], ASME IX [15] and API 6A [18]. The preparation of the specimens and notches was carried out by the process of wire electro-erosion.

The impact machine used has a pendulum with a mass of $18.750 \mathrm{~kg}$ and $30 \mathrm{kpm}$. The tests were performed at a temperature of $-18{ }^{\circ} \mathrm{C}$ according to the requirement of the API 6A standard [18]. The specimens were extracted from the welded joints so that the central region comprises the weld. The notches were positioned in two different locations: the first region corresponding to the fusion boundary (FB) along the interface between the AISI $8630 \mathrm{M}$ and Maraging 250, and the second in the Maraging 250 deposit, corresponding to the fusion zone. Both locations are indicated by dashed lines in Figure 4.

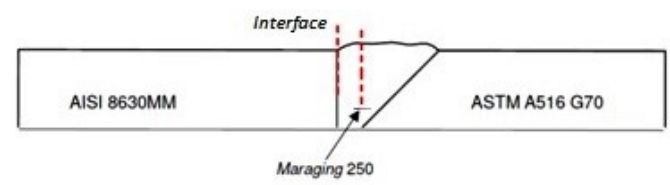

Figure 4. Charpy-V notch location in the front face of welded join.

The Vickers microhardness analysis was performed perpendicular to the fusion line, along the weld joint, comprising the fusion zone of Maraging 250, the dissimilar interface, the heat-affected zone (HAZ) and the base metal of the $8630 \mathrm{M}$ steel. The applied load was $50 \mathrm{~g}$ (HV 0.05) in the base metal and 500g (HV 0.5) in the weld metal, with the time of 15 seconds and a distance of $0.1 \mathrm{~mm}$ between each impression.

\section{Results and Discussion}

\subsection{Residual stress measurement}

Figure 5 shows the residual stress distributions along the longitudinal and transversal directions of the welded joint. The vertical dashed lines mark the edge of the weld metal. In the butt joint, the residual stress along both directions is compressive, suggesting that the Maraging 250 has effectively suppressed the tensile residual stress. This strongly suggests that the low transformation temperature weld metal, of which the martensitic transformation start temperature is low, reduced the residual stress more effectively.

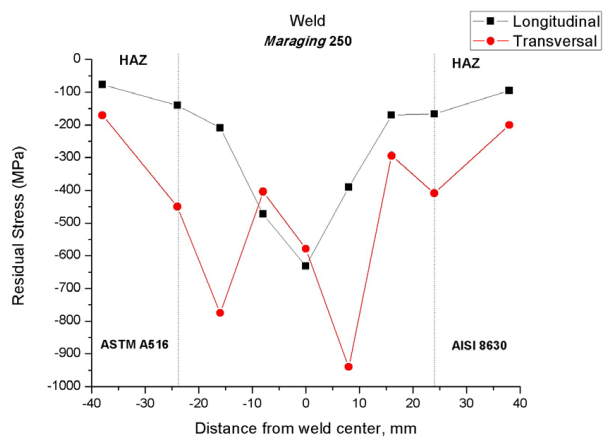

Figure 5. Residual stress distribution as a function of the distance from the weld centre on the top of the surface of the welded plates.

The residual stress profiles of the joint showed a compressive behaviour throughout the measured region, in the weld metal, in the heat-affected zone (HAZ) and in the base metals. It was assumed that the adiffusional phase transformations due to the use of the Maraging 250 steel filler metal were the main source of compressive residual stresses in the welded joint. 
The maximum residual stress levels were found on the ASTM A516 steel base metal, with tension peaks of $-77 \mathrm{MPa}$ in the longitudinal direction and $-171 \mathrm{MPa}$ in the transverse direction. The longitudinal residual stresses are more compressive (-632 MPa) in the Maraging 250 steel weld metal than in the base metals (-77 MPa) ASTM A516 G70 and (-95 MPa) AISI 8630MM.

The reduction in the magnitude of the residual stress in the heat-affected zone may be due to the fact that this zone is closer to the unaffected base metal, which is resistant, and reduces the ability to absorb the stress of the adjacent material of the heat-affected zone.

According to the study by Venkata Ramana et al. [19] on the residual compressive stress profiles in multi-pass weld metal welded with electrodes that present phase transformation when cooling, the residual compressive stresses were attributed to the sum of the effects of adiffusional phase transformations and stress gradients generated by the difference of the cooling rate along the thickness of the welded samples.

\subsection{Tensile tests}

In this study, the recommendations of the API 6A and ASME IX standards were adopted, which propose the use of a single specimen for the tensile test. Table 8 shows the results of the tensile test performed on the joint specimen. The properties obtained in this test, such as yield strength, ultimate tensile strength and elongation, met the acceptance criteria of the tensile test described by ASME IX; that is, the values remained within the range of acceptance of the minimum resistance limit tensile strength of the base metals, in this case the ASTM A516 Gr70 steel base metal. Therefore, the values obtained were higher than $485 \mathrm{MPa}$ for the tensile strength limit and $260 \mathrm{MPa}$ for the yield limit.

Table 8. Values of mechanical properties obtained in tensile tests for the welded joint.

\begin{tabular}{cc}
\hline Tensile strength $(\mathrm{MPa})$ & Yield limit $(\mathrm{MPa})$ \\
597.3 & 425.7 \\
\hline
\end{tabular}

The specimen ruptured on the ASTM A516 Gr 70 steel base metal, far from the weld, and the tensile strength value obtained in the test was greater than $95 \%$ of the tensile strength specified for the base metal, thus meeting the requirements of ASME IX. This result was due to the over-matching introduced by the Maraging 250 in relation to the base metal ASTM A516 Gr 70; that is, the filler metal employed has tensile and yield resistance superior to the resistance of the base metal.

Machado [20] comments that the use of overmatching reduces the mass of the filler metal, introducing generally undesirable and high residual stresses requiring special attention to defects originating from metallurgical phenomena, especially cracks induced by hydrogen. However, Boellinghaus and Kannengiesser [21] studied the effect of additional metal and contraction restriction on welding component stress in two welding conditions: the first in submerged arc welded joints of structural steel plates and the second in TIG orbital welding of super-tubular martensitic stainless steels. As a result, in both welding conditions the residual stresses transverse to the weld could be significantly reduced by selecting filler metals that lead to overmatching.

\subsection{Charpy impact tests}

Charpy impact tests were performed with notches positioned on the weld metal and on the Maraging $250 / 8630 \mathrm{M}$ steel interface. The tests were performed at $-18{ }^{\circ} \mathrm{C}$ according to API 6 A. The results obtained were respectively $46.1 \mathrm{~J} \pm$ StdDev at the interface and $47 \mathrm{~J} \pm \mathrm{StdDev}$ at Mar 250. Both values were higher than the $20 \mathrm{~J}$ required by the standard.

\subsection{Vickers microhardness}

Figure 6 shows Vickers microhardness profiles in the weld cross-section in 2 horizontal lines, called L1 (top) and $\mathrm{L} 2$ middle in weld metal points (WM) and the heat-affected zone (HAZ). The values required by NACE MR 0175 and DNV RP B401 standards are also represented in the Figure. The values stipulated by the standards aim to reduce the risk of stress corrosion cracking on the WM-HAZ interface. On the microhardness measuring surface, the dissimilar regions were identified as BM (AISI 8630M steel), HAZ (AISI 8630M heat-affected zone). 


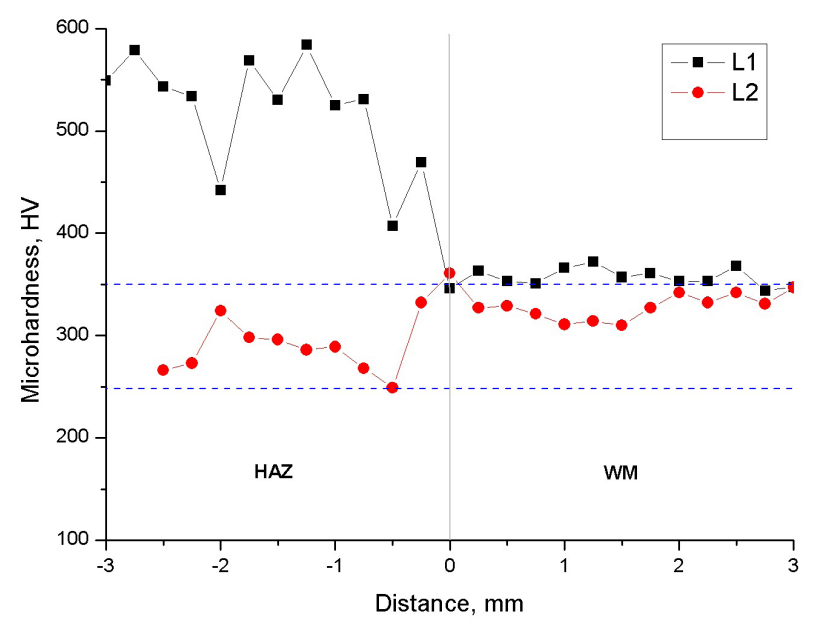

Figure 6. Profile of microhardness of the cross-section in lines L1 and L2 of the welded joint with Maraging 250.

It was observed that the hardness found in the fusion zone, constituted by the Maraging 250 weld metal, showed a significant reduction in the microhardness values when compared to the measurements performed along the HAZ cross- section, as shown in Figure 6, line L1. The increase in hardness in the HAZ region may be related to the modification of the microstructure by the welding heat cycle, which most probably resulted in the formation of hard microconstituents such as fresh martensite. The weld metal, Maraging 250, had microhardness close to $350 \mathrm{HV}$, consistent with the expected value between $300 \mathrm{HV}$ and $400 \mathrm{HV}$ for this material when it is in the as-welded or solution annealed condition. The stipulated limit for hardness in the standards is intended to prevent stress corrosion cracking. However, welding with Maraging steel 250 has resulted in residual stress levels much lower than those obtained with conventional electrodes. Considering line L2, a drop in microhardness along the HAZ was found, which suggests a tempering effect caused by subsequent heating cycles.

\subsection{Microstructural characterization of welded joint}

Figure 7 shows the microstructure of the weld metal for the MG 701 TIG alloy (Maraging 250). The microstructure presented was selected from a point away from the melting line. The microstructure showed a cellular solidification pattern structure characteristic of the melted zone reheated by welding passes. After solidification, the matrix suffered a phase transformation from austenite to martensite, as can be observed in Figure 8.

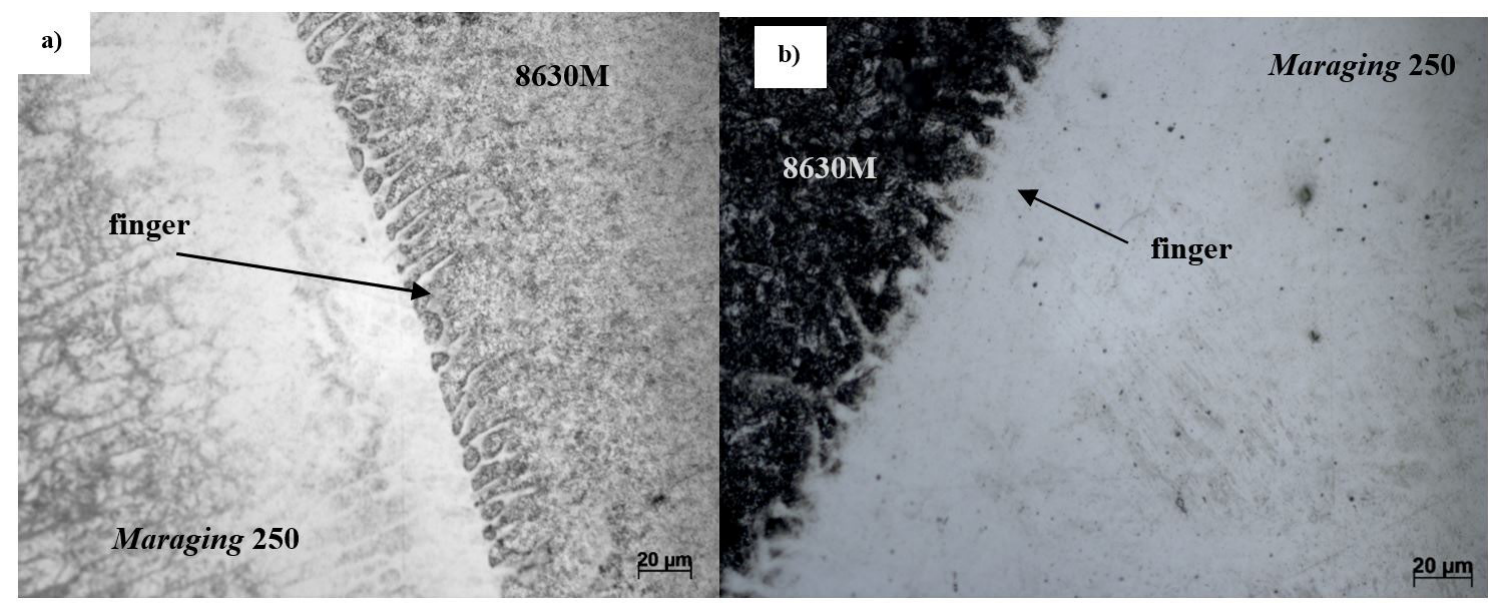

Figure 7. Refined grains in the HAZ (optical microscope images (a) Dendritic cell morphology in the fusion zone and with presence of "fingers" at the interface of welded joint; (b) The penetration of "finger" weld metal into the base metal). 


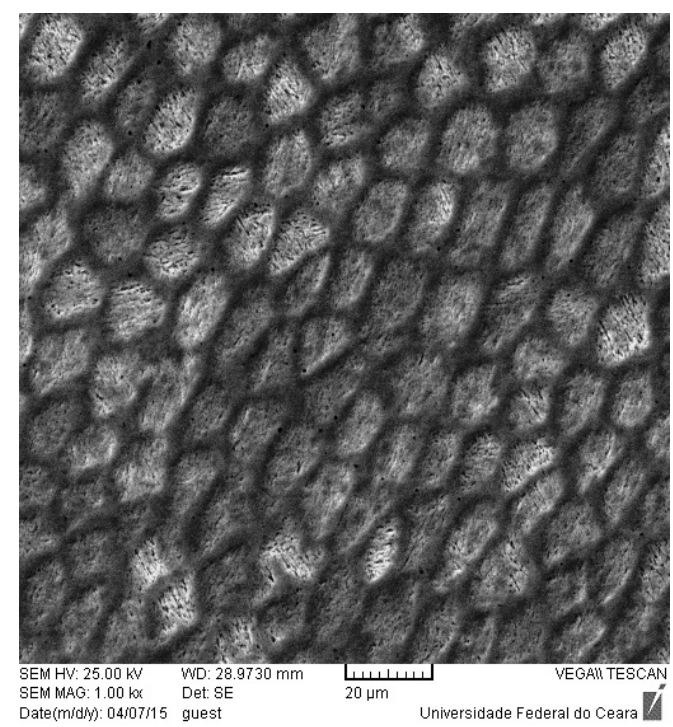

Figure 8. Microstructure of the welding metal Maraging 250. Nital $1 \%$.

\subsection{Heat-affected zone in AISI $8630 \mathrm{M}$ steel}

In the HAZ and interface of the welded joints of AISI 8630M steel with MG 701 TIG (Figure 7), the microstructure was identified as consisting of predominant martensite phase. The formation of this coarse grain zone can be due to the absence of carbon caused by the diffusion of the weld metal into the base metal. It is noted in Figure 7a that the microstructure of the fusion zone has dendritic cell morphology.

Throughout the fusion boundary, morphologies mentioned in the literature were observed, consisting of highly diluted zones due to macrosegregation that have an intermediate chemical composition to low alloy steel and nickel alloy, identified as zones subject to hard and brittle microstructures.

At the interfaces of all the welded joints of AISI 8630M steels, the presence of "fingers", weld metal penetrations in the base metal, was observed. The penetration of "finger" weld metal into the base metal suggests a high dilution, with high Fe content, apparently through the grain boundaries of the previous austenite.

Beugrand et al. [22] presented this structure in their studies, classifying the different forms found in high hardness zones, with martensitic microstructure, at the dissimilar interface of a welded joint with nickel alloy. These zones of high hardness, also known as "PDZ" (partially diluted zone) [23], can contribute to failure by hydrogen cracking, stress corrosion cracking and environments containing $\mathrm{H}_{2} \mathrm{~S}$.

According to Oliveira [24], the explanation of the formation of the "fingers", only in AISI 8630M steels, can be related to the fusion / solidification characteristics of the weld metal and the base metal. As can be seen in Figure 9, there is a shape variation in the interface structure between the AISI $8630 \mathrm{M}$ base metal and the MG 701 TIG weld metal (Maraging 250).

For Doody [25], the width of these hard zones significantly influences the onset of interface defects, since the PDZ can make a dissimilar weld susceptible to localized attack by pitting corrosion, hydrogen embrittlement, stress corrosion cracking in acid media and rupture due to fatigue.

It has been observed that the PDZs are formed in individual regions along the welded joint, whereas the majority of the interface between the weld metal and the base metal shows no heterogeneity. This fact was also reported by Kejelin et al. [26]. Concerning the hardness values obtained above $350 \mathrm{HV}$ in these regions, Doody [25] states that these zones may be susceptible to stress corrosion cracking and that these hardness values are within the characteristic hardness range of the martensitic microstructures (above $340 \mathrm{HV}$ ). Therefore, this particular region requires more attention due to its particular features. However, it must be pointed out that with compressive residual stresses within the weld region, including the fusion zone, heat-affected zone and interface, the risk of nucleating and propagating a cracking becomes lower when compared to high tensile stresses. 


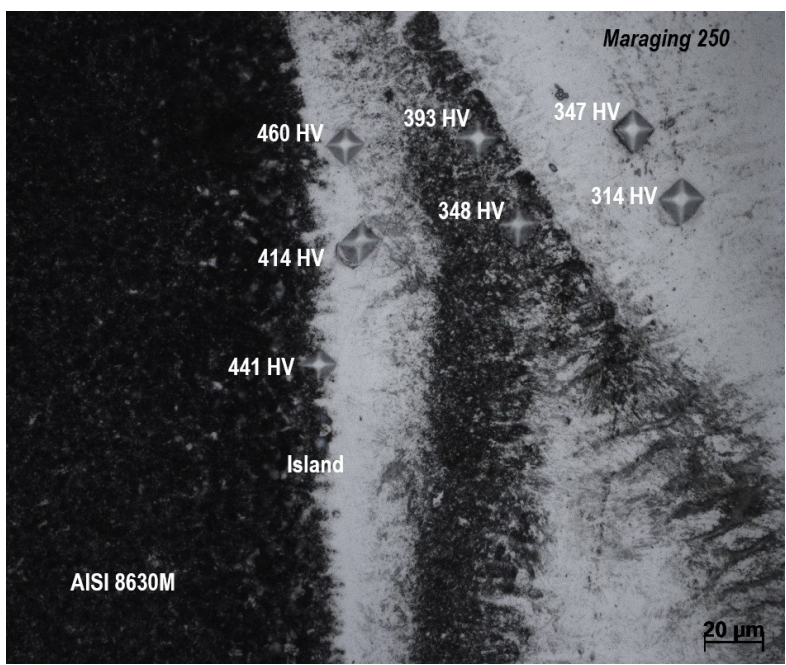

Figure 9. Base metal island at dissimilar interface of AISI 8630M base metal and Maraging 250 steel.

\section{Conclusions}

The present work with the objective of the application of Maraging 250 steel in dissimilar weld joints, allowed the following conclusions:

The Maraging 250 weld joint (low martensitic transformation) showed residual compressive stress intensities. The fusion boundary between the metal base and the weld metal presented a composition gradient creating regions with different mechanical properties, especially high hardness.

The values measured for Charpy impact energy in the weld metal and in the interface were in accordance with the API 6A standard.

The microhardness results allowed the evaluation of this property in the dissimilar interface of welded joints and showed that the results obtained were superior to those recommended by the NACE MR0175 and DNV RP B401 standards. However, the materials were presented in the solubilized condition without post weld heat treatment (TTPS).

The tensile tests performed on the specimen drawn from the joint welded with Maraging 250 met the acceptance criteria described by ASME IX. The values remained at the lower ultimate tensile strength of the less resistant base metals, in this case ASTM A516 G70 steel.

\section{References}

[1] Silva CC, Afonso CRM, Ramirez AJ, Motta MF, Miranda HC, Farias JP. Aspectos metalúrgicos de revestimentos dissimilares com a superliga à base de níquel inconel 625 . Soldagem e Inspeção. 2012;17(3):251-263. http://dx.doi.org/10.1590/ S0104-92242012000300009.

[2] Silva CC, Afonso CRM, Ramirez AJ, Motta MF, Miranda HC, Farias JP. Assessment of microstructure of alloy Inconel 686 dissimilar weld claddings. Journal of Alloys and Compounds. 2016;684:628642. http://dx.doi.org/10.1016/j.jallcom.2016.05.231.

[3] Withers PJ, Bhadeshia HKDH. Residual stress, part 2: nature and origins. Materials Science and Technology. 2001;17(4):366-375. http://dx.doi.org/10.1179/026708301101510087.

[4] Saraiva DL, Béreš M, Silva CC, Nunes CS, Silva JJM, Abreu HFG. Application of low Ms temperature consumable to dissimilar welded joint. Materials Science and Technology. 2014;30(9):10571062. http://dx.doi.org/10.1179/1743284714Y.0000000516.
[5] Bhadeshia HKDH. Developments in martensitic and bainitic steels: role of the shape deformation. Materials Science and Engineering A. 2004;378(1-2):34-39. http://dx.doi.org/10.1016/j. msea.2003.10.328.

[6] Ohta A, Matsuoka K, Nguyen NT, Maeda Y, Suzuki N. Fatigue strength improvement of lap joints of thin steel plate using low-transformation-temperature welding wire. Welding Journal. 2003;82:78S-83S.

[7] Wang WX, Huo LX, Zhang YF, Wang DP, Jing HY. New developed welding electrode for improving the fatigue strength of welded joints. Journal of Materials Science and Technology. 2002;18:527531.

[8] Murakawa H, Béreš M, Vega A, Rashed S, Davies C, Dye D, et al. Effect of phase transformation onset temperature on residual stress in welded thin steel plates. JWRI. 2008;37(2):75-80. 
[9] Pawlak SJ, Zalecki W. Microestructure, properties and hot deformability of the new maraging steels. Jounal of Achievements in Materials and Manufacturing Engineering. 2008;29:31-38.

[10] Sha W, Guo Z. Maraging steels: modelling of microstructure, properties applications. Washington: Woodhead Publishing; 2009.

[11] Farooq M, ul Haq A, Hashmi FH, Khan AQ. Microscopic determination of austenite in 18\% Ni Maraging steel. Metallography. 1987;20(3):377383. http://dx.doi.org/10.1016/0026-0800(87)90046-2.

[12] American Society for Testing and Materials. ASTM A322-07: standard specification for steel bars, alloy, standard grades. West Conshohocken: ASTM; 2007.

[13] International Organization for Standardization - ISO. NACE MR0175/ISO 15156:2003: petroleum and natural gas industries: materials for use in $\mathrm{H} 2 \mathrm{~S}$ environments in oil and gas production. Part 2: cracking resistent carbon and low alloy steels and the use of cast iron. Geneva: ISO; 2003.

[14] Det Norske Veritas Industri Norge AS - DNV GL. RP B401: cathodic protection design. Oslo: DNV GL; 2008.

[15] American Society of Mechanical Engineers. ASME IX edition: boiler and pressure vessel code, section IX: welding and brazing qualifications. New York: ASME; 2009.

[16] American Society for Testing and Materials. ASTM A370: standard test methods and definitions for mechanical testing of steel Products, revision 17a. West Conshohocken: ASTM; 2017.

[17] American Society for Testing and Materials. ASTM E23: standard test methods for notched bar impact testing of metallic material. West Conshohocken: ASTM; 2007.

[18] International Organization for Standardization - ISO. API 6A/ ISO 10423:2004: specification for wellhead and christmas tree equipment. 19th ed. Geneva: ISO; 2004.
[19] Venkata Ramana P, Madhusudhan Reddy G, Mohandas T, Gupta AVSSKS. Microstructureand residual stress distribution of similar and dissimilar electronbeamwelds: maraging steel to medium alloy medium carbon steel. Materials \& Design. 2010;31(2):749760. http://dx.doi.org/10.1016/j.matdes.2009.08.007.

[20] Machado IG. Novos paradigmas para especificação de juntas soldadas. Soldagem e Inspeção. 2012;17(3):278-288. http:// dx.doi.org/10.1590/S0104-92242012000300012.

[21] Boellinghaus T, Kannengiesser T. Effect of filler material selection and shrinkage restrain on stress strain build up in components weld. In: Proceedings of the 6th International Trends in Welding Research Conference; 2003; Phoenix, Arizona. Materials Park: ASM International; 2003. p. 906-911.

[22] Beugrand VCM, Smith LS, Gittos MF. Subsea dissimilar joints: failure mechanisms and opportunities for mitigation. In NACE Corrosion 2009; 2009; Atlanta, Georgia, USA. Texas: NACE; 2009. Paper no 09305.

[23] Kejelin NZ, Buschinelli AJA, Pope AM. Influence of welding parameters on the formation of partially diluted zones of dissimilar metal welds. Soldagem e Inspeção. 2007;12:112-123.

[24] Oliveira GLG. Soldagem dissimilar dos aços AISI 8630M e ASTM A182 F22 para aplicações subaquáticas [tese]. Fortaleza: Universidade Federal do Ceará; 2013.

[25] Doody T. Intermediate mixes zone in dissimilar metal welds for sour service. Welding Journal. 1992;71:55-60.

[26] Kejelin NZ. Influência dos parâmetros de soldagem na formação de zonas parcialmente diluídas em soldas de metais dissimilares [dissertação]. Florianópolis: Programa Pós-graduação em Ciência e Engenharia de Materiais, Universidade Federal de Santa Catarina; 2006. 